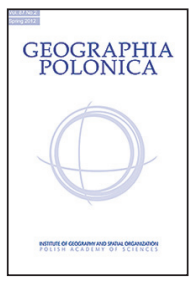

\title{
POLISH PRECURSORS TO THE IDEA OF THE POLITICAL UNIFICATION OF EUROPE
}

\author{
PIOTR EBERHARDT \\ Institute of Geography and Spatial Organization \\ Polish Academy of Sciences \\ Twarda 51/55, 00-818 Warszawa, Poland \\ E-mail: p.ebe@twarda.pan.pl
}

\begin{abstract}
The paper outlines the creative achievements of nine Polish scholars and political activists living in the eighteenth and nineteenth centuries. They were the precursors of the idea of the political unification of Europe. They argued, in their various works, that it was necessary to establish the unity and brotherhood of the nations of Europe. They postulated the liquidation of political boundaries and the establishment of a community of free states on the European continent.
\end{abstract}

Keywords: Europe, $18^{\text {th }}$ and $19^{\text {th }}$ centuries, integration concepts

\section{INTRODUCTION}

Polish scholars and political activists in the eighteenth and nineteenth centuries created the visions of and the designs for the political unification of Europe. Their achievements in this domain are significant, interesting and innovative. The Polish concepts within the domain that this article discusses, emerged in a particular European context. They are virtually unknown in Polish society. ${ }^{1}$ They are rarely mentioned in geographical, historical and politological studies. Likewise, there is very little discussion of these figures in international forums. The reasons for this state of affairs are quite complex. Our knowledge of the content of the archives is incomplete. The academic and political research of numerous scholars and activists has not become the subject of analyses and assessments. Despite these distinct gaps,

1 One of the few Polish researchers, who has recently dealt with these problems, is A. Marszałek (1996, 2000, 2005). In his books, he placed the Polish and the foreign work in an historical perspective. His publications contain an ample bibliography. A similar systematic character is displayed also only by the most recent survey publication by A. Borzym and J. Sadowski (2007), S. Michałowski (1999/2000) and W. Wierzbicki (2009). the knowledge that we do have indicates the high quality of Polish thinking when it came to the idea of the unification of European countries and nations. This subject was taken up by Polish scholars, who between them represented a broad range of knowledge and possessed outstanding intellectual qualities. Among the most important in terms of their concepts and visions were:

\section{STANISŁAW LUBIENIECKI}

The very first consistent geographical programme drawn up by a Pole, which advanced the notion of the unification of a large part of Europe, is believed to be contained in a memorandum written by Stanisław Lubieniecki (1623-1672)2. This memorandum

${ }^{2}$ Stanisław Lubieniecki was active in science and politics. He was the leader of the Arian religious emigration, having left Poland in the era of the counterreformation. At the same time, he was an outstanding astronomer and the author of numerous books, as well as religious and political essays. Selected writings of Lubieniecki were published by the Institute of Philosophy and Sociology of the Polish Academy of Sciences in the original Latin language, as the facsimiles of the original publications (S. Lubieniecki, 1971). There are sources which maintain that the great Ger- 
was addressed in 1671 to Louis XIV, the then king of France. In this memorandum Lubieniecki proposed the establishment of a great European empire, stretching from Italy to Poland, under the supremacy of France. Louis XIV, being the legitimate successor of Charles the Great, would assume the leadership of this Empire, becoming the Roman Emperor. The memorandum listed twenty arguments, justifying the proposal for European unity. ${ }^{3}$ In the final remarks of the memorandum the author expressed his certainty that such a concept would conform to God's will, and that one should follow it, in accordance with the principle of ducunt volentem fata, nolentem trahunt [the fates lead the willing and drag the unwilling].

\section{KING STANISŁAW LESZCZYŃSKI}

The Polish king, Stanisław Leszczyński (1677-1766), was a visionary who consistently put forward the idea of the political unity of the European nations and states. Given that he occupied the Polish throne on two occasions, he is quite well known, and his political activities, along with his creative achievements, have been the subject of numerous analyses and evaluations ${ }^{4}$. After he definitively lost the Polish throne, he emigrated and settled in France. There, owing to the support from his father-in-law, King Louis XV of France, he went on to rule the duchy of Lorraine and Bar. While serving as the prince, he started to write. In particular, he wrote a work entitled "Memorandum on the safeguarding of the universal peace", in which he presented the design for the estab-

man philosopher Wilhelm Leibnitz (1646-1716) was descended from the Polish family of Lubieniecki.

3 These arguments were commented upon in a book devoted to the life and work of Lubieniecki, written by an outstanding Polish historian, J. Tazbir (1961, 2003).

${ }^{4}$ Among the most important monographs devoted to Stanisław Leszczyński, one should cite those by J. Feldman (1948) and J. Lechicki (1951). The latter publication contains the more important works written by one of the last Polish elected kings. lishment of a European League of Nations ${ }^{5}$. The proposed organization, encompassing all European countries, would function under the protectorate of France. Its fundamental goal would be to ensure persistent peace and to liquidate at the outset all the conflicts between European countries.

The thus established European community, which he termed "league", would be a freely established alliance of European states. This would be, according to the author of the design, a guarantee of a stable peace. In an ideological and conceptual sense, the design of King Stanisław Leszczyński was a visionary and exceptional creation. It is worth noting that a very similar concept was realized after World War I in the form of the League of Nations, established following the Treaty of Versailles.

\section{KAJETAN JÓZEF SKRZETUSKI}

Another, later Polish scholar who wrote a lot on the subject of a freely established alliance of all European countries was K. J. Skrzetuski (1743-1806) ${ }^{6}$. He was inspired by the work of the outstanding French philosopher, Jean-Jacques Rousseau. He translated some of Rousseau's writings into Polish. Coming under the influence of the French

5 The author, who presented to the readers the concept of the unity of the European countries, developed by King Stanisław Leszczyński, was J. Życki (1932). This concept was thereafter recalled in the scientific reports and in journal papers.

${ }^{6}$ The works of K. J. Skrzetuski were written during a very notable historical period. This was, namely, the time of the first partition of the Polish-Lithuanian Commonwealth. The works of Skrzetuski were mainly published in the years 1773-1775; that is, soon after the partition. This, beyond doubt, had an important influence on the ideological message from the author. He thought that only a new European order could have saved the Commonwealth. The publications of K. J. Skrzetuski, written long ago, have not been published again since. For this reason, information on the work and achievements of this interesting political writer originate from various sources and are quite fragmentary. The most informative is the report by W. Bokajło (1998, pp. 191-193). 
Enlightenment, he presented the vision of a unified Europe. He assumed that only the establishment of political unity would ensure peace and put an end to fratricidal wars. He proposed the establishment of a league of states and the creation of a Congress (General Diet), in which the representatives of all the European countries would have guaranteed full participation. Congress would play the supreme role, endowed with the task of arbitrating between particular European countries. The basis for the European order would be constituted by the status quo. Political boundaries would be stable. The verdicts of the General Diet would be final. In a case of non-subordination to its decision, the European community would have the right to intervene militarily. One can note that the contemporary Security Council of the UN functions on the basis of similar principles. According to the author of this design, such a confederation would be able to ensure the peace and security of every country, including Poland, who should initiate the activities whose objective would be the establishment of a league of European nations.

\section{STANISŁAW STASZIC}

Stanisław Staszic (1755-1826) presented the original vision of European unity ${ }^{7}$. This great philosopher, naturalist and political activist was a promoter of the idea of the rights of nations and also of the personal freedom of every human being. He thought that Poland's loss of sovereignty was a great catastrophe for all Polish citizens. He was aware of the fact that attempts to regain independence by waging war on the partitioning pow-

7 The works of Stanisław Staszic have been published several times over and are commonly known (Staszic, 1954, 1959). Against the background of the great scholarly achievements of this scientist, his thoughts on politics, and especially geo-politics, have usually been considered less interesting and have not been subject to a deeper interpretation. It was only W. Feldman (1913), who emphasized the role of Stanisław Staszic in the development of Polish political thought. ers would be doomed to failure. He therefore sought some other way that could lead to a complete change to the existing political constellations. This could take place through a global reorganization of the system of international relations and the establishment of a grand federation, which would be an association of numerous European regions and countries.

Staszic believed that the future of the continent belonged to the Slavonic nations. Only these nations were capable of forming a new civilization, and their overwhelming political force might bring about European unity. This necessitated the joining of the efforts of the Russians and the Poles. Were the two opposing Slavonic nations to work together, the possibility would exist of uniting a large part of Europe. The formation of such a great country would influence the remaining, fragmented parts of Europe. Ultimately, an era of Slavonic civilization would arise, which would ultimately lead to a new, final unification of Europe on the basis of new cultural values. Despite their clearly utopian overtures, the designs of Staszic should not be entirely dismissed. His goals were the unification of Polish territory, and the liquidation of the partitioning frontiers. These would be guaranteed by the future Slavonic empire. European unity, initiated in the East, and then gradually encompassing the countries of Western Europe, was meant to ensure the improvement of the situation of smaller countries and nations.

\section{JÓZEF HOENE-WROŃSKI}

An outstanding mathematician, philosopher and economist, Józef Maria HoeneWroński (1776-1853) ${ }^{8}$, to a large extent continued the thought of Stanisław Staszic. According to his views, the Romance and Germanic nations had already fulfilled their

${ }^{8}$ The literature on the work of Hoene-Wroński is not too abundant. Against this background, a survey monograph by B. J. Gawecki (1958), which contains ample documentation and a bibliography, is definitely worth attention. 
historical role. The era of the young Slavonic nations was coming. The "Slavonic world" would be the new engine of progress in Europe. The Russian emperor faced the great tasks of annihilating Western Europe which was in decline and of establishing a new civilization, based on Eastern European spiritual values. He saw the latter mainly in Eastern Orthodox Christianity and in the culture of the Russian people. Hoene-Wroński also appreciated the military power and the organizational capabilities of the despotic czarist authority. Were the two biggest Slavonic nations - the Russians and the Poles - to reach an historic agreement, it would become possible to start constructing a great Slavonic confederation. The power that would result from this should ultimately lead to European unity. Within this great community, promising perspectives should open for the development of national life for Poles ${ }^{9}$.

\section{WOJCIECH BOGUMIL JASTRZĘBOWSKI}

The concept consistently put forward by the little known naturalist and philosopher Wojciech Bogumił Jastrzębowski (1799$1882)^{10}$ constitutes an exceptionally interest-

${ }^{9}$ It can be seen from the considerations contained here that both Staszic and Hoene-Wroński were followers of the pro-Russian and pan-Slavic ideology. They thought that only under the leadership of a powerful Russia would there exist the possibility of establishing a great European federation in which Poland would be one of the essential elements of the community. This was supposed to change completely the image of Poland, Europe and the world.

${ }^{10}$ During many decades the design for the establishment and functioning of the European community, authored by W. B. Jastrzębowski, remained forgotten and was not referred to in the literature of the subject. Supposedly, the first figure to recall this interesting concept was J. Iwaszkiewicz (1937). This concept, because of its value and novelty, also attracted the attention of an English historian living in Toronto, P. Brock (1967). In recent years, in the new political conditions, the work of W. B. Jastrzębowski has come to be considered as being increasingly important and became the object of deeper analyses. In this context, one can mention, for instance, the publi- ing work, whose value in terms of subject matter has been increasingly appreciated over time. This particular design is particularly important because of its exceptional value both in terms of the interesting nature of its content and its original form. Nowadays, W. B. Jastrzębowski is treated as a great visionary, who, owing to his anticipatory projection, deserves the title of patron of the modern European Union. He launched a dramatic appeal, calling for the political unity of the nations of Europe. His memorandum, published in 1831, entitled "Treaty on the eternal alliance between the civilized nations" was an exceptional work, both in view of the originality of thought and the manner in which it defended its arguments.

Jastrzębowski chose for his concept the form of a constitutional document, composed of 75 articles. Taken together, they form an outline for the functioning of a great federation, encompassing all the nations of Europe. The subject of law, namely, in the future, would be constituted by the nations, and not the countries or states.

The proposed constitution was meant to secure eternal peace in Europe. The goal of securing peace would remain within the competence of the European Congress. Membership of the community would be a moral obligation and would constitute evidence of the level of civilization of each of the European nations. Those nations who declined to adhere to the Congress would be treated as "barbarian" nations. At the same time, Jastrzębowski did not consider Europe as a continent limited by geographical boundaries.

The highest law-making, executive and judiciary power would be wielded by the established Congress of Europe. It would, simultaneously, play the role of an authority that could be appealed to by the national administrations, preserving the sovereignty of the latter. As far as law-making competence is concerned, national laws would remain the

cations of B. Kubicka-Czekaj (1994) and B. Dymek (2003). In both these reports the complete text of the so-called Constitution for Europe, authored by Jastrzębowski, is cited. 
exclusive domain of the national level, while European laws would be enacted by the Congress and would apply to all the European nations.

In the final part of the memorandum, the author sketches his visions of the future, which would be devoid of war and conflicts. According to him, the adoption and acceptance of the proposed Constitution and the establishment of the Europe of Nations would be the beginning of an era of "eternal alliance in Europe". Thus, it can be concluded beyond doubt that Jastrzębowski was the precursor of the contemporary European Union. His enlightened and far-reaching ideals were eventually implemented many decades later. Many of his original formulations, even though worded differently, but with identical content, can be found in the fundamental documents signed by the member countries of the European Union. Jastrzębowski was an advocate of the modern variety of unification, trying to free the inhabitants of Europe of particular conflicts and potential threats. He postulated the establishment of a common and unified legal space. He articulated federalist ideas. Pacifism, liberalism and humanism were close to him. Yet, he transgressed the rationality of the then passing epoch of the Enlightenment with his clear romanticism, which was pervaded with idealism.

\section{PRINCE ADAM JERZY CZARTORYSKI}

Prince Adam Jerzy Czartoryski (1770$1861)^{11}$ played an important role in the development of Polish political thought. This outstanding activist and thinker, spiritual representative of the then non-existent Poland, wrote a lot on the subject of the future of Europe. He developed a consistent idea, postulating the unification of all the Euro-

${ }^{11}$ Many publications, authored by A. J. Czartoryski, appeared during his life. They were also reedited and published after his death. Quite recently, for instance, a book was published, containing the excerpts from the main political works, written by this great Polish thinker and politician (A. J. Czartoryski, 1992). pean nations in one all-embracing community ${ }^{12}$. Being aware of the cultural diversity of the European nations, he proposed - in a similar vein to W. B. Jastrzębowski - the establishment of the so-called "Europe of Nations", in which every nation would find a secure and appropriate place ${ }^{13}$.

The very first concept of the new European order was elaborated by Prince Czartoryski in 1803 and was presented to the Emperor Alexander I of Russia. In this concept, Czartoryski proposed that Russia, while engaged militarily against the policies of Bonaparte, consistently aimed at the formation of four federations as the basis for the political unity of Europe:

1)The French federation (France, together with Belgium and Spain)

2)The Federation of the Slavonic peoples

3)The Germanic federation, with the Netherlands and Switzerland, but without Prussia and Austria

4)The Federation of the Italian countries.

The views of Czartoryski on the European question are also contained in the political treaty, published in 1826, entitled "Essai sur la diplomatie" (Essay on diplomacy). $\mathrm{He}$ criticized the treaty as reflecting traditional diplomacy and the decisions taken at the Congress of Vienna in 1815. He maintained, then, that the collaboration of the three partitioning powers (the so-called alliance of the three black eagles, Russia, Prussia and Austria) constituted a danger not only for Poland, but also for Europe. That is why it was necessary to change deeply the principles of international politics and law. The foundations thereof ought to be constituted by the right of the European nations to freedom and

12 There is an abundance of literature devoted to the political and creative activity of A. J. Czartoryski. One should mention, first and foremost, the publications of M. Handelsman (1948-49), and the more recent ones of J. Skowronek (1994), M. K. Dziewanowski (1998) and M. Kukiel (1993, 2008).

${ }^{13}$ An in-depth interpretation of the work of A. J. Czartoryski was presented by A. Nowak (1998). He focused his attention especially on the design of the so-called Europe of Nations. 
independence. This would be guaranteed by a "League of Nations", a body that would ensure peace and international cooperation. In order to achieve this goal, the collaboration of England with France would be necessary, with additional support from Russia. This kind of a political setting would form the core of the united Europe.

The Spring of Nations presented new possibilities for political activity. Prince Czartoryski developed in this period the visions of a supra-national community stretching from the Balkans to France, such a community being capable of changing the political status of Poland. A revival of the activity of Prince Czartoryski took place during the period of the Crimean War. He hoped that Russia would be weakened as a result of the war and, therefore, for the establishment of a new European order. Despite the fact that the consecutive designs failed, and the reality did not develop according to the expected scenarios, the Prince continued to be active in the political domain. As a consequence of the political changes, his visions would undergo far reaching modifications. Yet he was constantly faithful to the great idea of the rights of nations of Europe to the sovereign existence in the framework of states. At the same time he articulated the necessity of establishing the federative settings, based on the models of freedoms, developed over centuries in Western Europe.

\section{ZYGMUNT EDWIN GORDASZEWSKI}

We owe this little known design of creating a federation of free European countries to the political writer, associated with the Polish Great Emigration, following the November Uprising of 1830-31, to Zygmunt Edwin Gordaszewski (1806-1862). In a pamphlet, written in 1848 in French at Fontainebleau, and published in the same year in Paris, he presented the legal prerequisites for the functioning of a political community that encompassed all European countries ${ }^{14}$. In the

14 The article of Z. E. Gordaszewski, entitled introduction to this short text he appealed to all the powers of the world, arguing for the need of unity and adherence to a global federation. Gordaszewski formulated, then, the principles of federation, allowing for the unification of the free states.

\section{STEFAN BUSZCZYŃSKI}

Stefan Buszczyński (1821-1892) was the author of a grand work, entitled "Upadek Europy" ("The decline of Europe") ${ }^{15}$. He presented in this book the tragic image of European reality in the middle of the nineteenth century. The sole solution in the context of the approaching social catastrophe was to carry out radical reform of the existing political system. He presented a design for such changes in a dissertation published in Leipzig in 1875. According to this document, every nation ought to form an independent political whole, the so-called "ethnopolis". These entities, and not states, should become a persistent foundation for the future united Europe. For purposes of safety and defence the ethnopolises ought to join together, forming political alliances (coenopolises). The latter would be headed by the Coenopolic councils, composed of the delegates of all the participating ethnopolises. The duty of the council would be to elaborate the system of principles that regulated mutual relations between the confederated ethnopolises.

Such a design ought to secure for Europe "universal peace" and political equilibrium, based on the "natural" system of national alliances. As has been mentioned, for the purposes of strengthening their safety, those na-

\footnotetext{
"Fédération générale des états libres" ("General federation of free states"), was translated from French and published in the selection of texts, edited by $\mathrm{P}$. O. Loew (Polskie.., 2004, pp. 70-75). As a result, this document, forgotten by scholars, was again brought to light.

15 This work, of which only a small number of copies were published after the death of its author, is hardly accessible nowadays and is little-known to historians. It is highly original both in terms of its content and form (S. Buszczyński, 1896).
} 
tions that were similar to each other in terms of origins and culture ought to form between them the coenopolic alliances. The author then enumerated ten such possible alliances in Europe ${ }^{16}$ :

1. German coenopolis

2. British coenopolis

3. Scandinavian coenopolis

4. Italian-Iberian coenopolis

5. French coenopolis

6. Czech-Serb coenopolis

7. Polish coenopolis, encompassing the territory of the Polish-Lithuanian Commonwealth from before the first partition; that is, from before 1772, as well as Silesia, it having belonged to the medieval Kingdom of Poland

8. Muscovite coenopolis

9. Hungarian-Romanian coenopolis, and

10. Greek-Turkish coenopolis.

The coenopolises listed above, which were referred to as the "principal coenopolises", should, in turn, associate themselves - according to a "racial-cultural" criterion - into the confederations of a higher order, described by the author as the "tribal coenopolises", namely:

1. The German coenopolis, together with the British and the Scandinavian ones, should form a tribal Germanic coenopolis. In order to preserve the political equilibrium inside this tribal coenopolis, Buszczyński proposed that the British and Scandinavian coenopolises establish a British-Scandinavian alliance, as an effective counterweight to the German coenopolis.

2. The Italian-Iberian and French coenopolises ought, in turn, join to form the tribal Romance coenopolis.

3. The association of the Serb-Czech coenopolis with that of the Polish would give rise to the Slavonic tribal coenopolis.

4. The fourth tribal coenopolis could be

${ }^{16}$ The design by $\mathrm{S}$. Buszczyński is presented in two contemporary publications (K. K. Daszyk, 2001; T. Marczak, 2004). In the first of them the life and creative work of S. Buszczyński are presented in an interesting manner. constituted by the Muscovite coenopolis, which, in terms of the "racial-cultural" criterion, could be referred to as the Turanian coenopolis.

5. Finally, an amalgamation of the Hungarian-Romanian coenopolis with the GreekTurkish one could give rise to the racially mixed Eastern coenopolis.

As a result of this, in the subsequent phase, three similar, in terms of population numbers and the associations of nations (the tribal Germanic coenopolis, the tribal Romance coenopolis, and the Slavonic-Turanian alliance), would emerge in Europe. Such a political setting of forces would guarantee for the inhabitants of Europe the long awaited, persistent "universal peace".

Buszczyński considered Europe as a common home for all the Europeans (Germanic, Romance and Slavonic peoples). Notably, however, in his design he consistently denied the right of Russia to call itself Slavonic. In his opinion the dominating ethnic elements among the Russians were the Finn and Mongol elements, with the Slavonic element being clearly subservient to the other two. ${ }^{17}$

Buszczyński proposed an appropriate organization for the system of authority in the ethnopolises and in the coenopolises.

The prospect of decline, which Europe faced, could be averted only through the adoption as the foundation the universal freedom, based on universal education. Then, the sole means of realizing this task would be to unite all the European nations.

One would think that nowadays, when Buszczyński's dreams have, to a large extent, become a reality, this outstanding Polish scholar of the nineteenth century ought to be recalled and considered as being one of the conceptual precursors of the establishment of the contemporary European Union.

${ }^{17}$ S. Buszczyński was the follower of the known theory of Franciszek Duchiński (1859, 1861), who did not consider Russia to be a Slavonic country. He treated the Muscovites (Russians) as a MongolTartar-Finn people. 


\section{FINAL REMARKS}

This article has outlined the ideas of nine Polish political thinkers and activists, living in the eighteenth and nineteenth centuries, and demonstrates that Polish achievements, when it came to the creation of concepts for the political unification of Europe, are characterized by exceptional diversity. This concerns as much the substance of the concepts put forward as the forms in which they were presented. Despite the passing of time an important part of the ideas of these Polish political thinkers has not lost its intellectual value (like, for instance, the concepts of Jastrzębowski or Buszczyński). They might still constitute an inspiration for the activists working for the deeper integration of Poland with the European Union.

\section{REFERENCES}

Bokajło, W. (1988), Historyczne tło polskiego federalizmu [Historical background of Polish federalism], in Bokajło, W. (ed.), Federalizm. Teorie $i$ koncepcje [Federalism. Theory and concepts], Wydawnictwo Uniwersytetu Wrocławskiego, Wrocław.

Borzym, A., Sadowisk, J. (2007), Polscy ojcowie Europy [The Polish fathers of Europe], Wydawnictwo TRIO, Warszawa.

Brock, P. (1967), A Pacyfist in Wartime: Wojciech Bogumit Jastrzębowski, The Polish Review, 12, 2, pp. 68-77, New York.

Buszczyński, S. (1896), Upadek Europy [The decline of Europe], Vol. VIII, Drukarnia Związkowa, Kraków.

Czartoryski, A.J. (1986), Pamiętniki i memoriały polityczne 1776-1809 [Political memoirs and memoranda: 1776-1809], Instytut Wydawniczy PAX, Warszawa.

Czartoryski, A.J. (1992), Polityka kieruje nie tylko interes ale i moralność. Wybór myśli politycznych i społecznych [Politics is governed not only by interest but also by morality. A selection of political and social thoughts], Wydawnictwo Neriton, Warszawa.

Daszyk, K.K. (2001), Strażnik romantycznej tradycji Rzecz o Stefanie Buszczyńskim
[A guardian of the Romantic tradition. The thing about Stefan Buszczyński], Towarzystwo Wydawnicze „Historia Jagiellonica", Kraków.

Duchiński, F. (1859), (1861), Zasady dziejów Polski i innych krajów słowiańskich $i$ Moskwy [The principles of the history of Poland as well as of other Slavic countries and Moscow], Printing and lithographing by Renon and Maulde, vol. I, II, III, Paris.

Dymek, B. (2003), Wizja przymierza między narodami Europy z 1831 r. wedlug Wojciecha Bogumiła Jastrzębowskiego [A vision of an alliance between the nations of Europe of 1831 by Wojciech Bogumił Jastrzębowski], Mazowieckie Towarzystwo Naukowe, Warszawa.

Dziewanowski, M.K. (1999), Ksiażę wielkich nadziei [A prince of great hopes], Biografia Księcia Adama Jerzego Czartoryskiego [Biography of Prince Adam Jerzy Czartoryski], Atlas, Wrocław.

Feldman, J. (1948), Stanisław Leszczyński, Książnica Atlas, Wrocław, Warszawa.

Feldman, W. (1913), Dzieje polskiej myśli politycznej $w$ okresie porozbiorowym (próba zarysu) [A history of Polish political thoughts in the pre-partition period (presentation of the outline)], vol. I, Spółka nakładowa Książka, Kraków.

Gawecki, B.J. (1958), Wroński i o Wrońskim. Katalog prac filozoficznych HoeneWrońskiego oraz literatury dotyczacej jego osoby i filozofii [Wroński about Wroński. A catalogue of philosophical works by HojneWroński and of the literature written about this person and his philosophy], Państwowe Wydawnictwo Naukowe, Warszawa.

Gordaszewski, Z.E. (1848), Fédération générale des états libres, A la librairie nationale de J Bry, Paris.

Grygajtis, K. (2001), Polskie idee federacyjne $i$ ich realizacja $w$ XIX $i X X$ wieku [Polish ideas of federalism and their realization in the nineteenth and twentieth centuries], Wydawnictwo Wyższej Szkoły Pedagogicznej, Częstochowa.

Handelsman, M. (1948-1949), Adam Czartoryski, Nakładem Towarzystwa Naukowego Warszawskiego, vol. I, II, Warszawa. 
Iwaszkiewicz, J. (1937), Nieznany polski projekt wiecznego pokoju [An unknown Polish project of lasting peace], Polityka Narodów, 9, 4, Warszawa.

Kubicka-Czekaj, B. (1994), Wojciecha Bogumiła Jastrzębowskiego Konstytucja dla Europy z 1831 r. [A constitution for Europe as of 1831 by Wojciech Bogumił Jastrzębowski], Towarzystwo Literackie im. A. Mickiewicza, Oddział w Częstochowie, Częstochowa.

Kukiel, M. (1993), Ksiaże Adam [Prince Adam], Wydawnictwo PAVO, Warszawa.

Kukiel, M. (2008), Czartoryski a jedność Europy 1770-1861 [Czartoryski and a unity of Europe 1770-1861], Instytut Europy Środkowo-Wschodniej, Lublin.

Lechicki, J. (1951), Rola dziejowa Stanistawa Leszczyńskiego oraz wybór jego pism [Stanisław Leszczyński's role in history and a selection of his works], Towarzystwo Naukowe, Torun.

Lubieniecki, S. (1971), Historia reformationis polonicae, Biblioteka Pisarzy Reformacyjnych [Library of the Reformation writers], 9, H. Barycz, Państwowe Wydawnictwa Naukowe, Warszawa.

Marczak, T. (2004), Stefan Buszczyński i jego wizja Europy [Stefan Buszczyński and his vision of Europe], in S. Ciesielski, T. Kulak, K. Ruchniewicz, J. Tyszkiewicz (eds.), Wokót historii i polityki. Studia z dziejów XIX $i$ XX wieku [Of history and politics. Studies into the history of the nineteenth and twentieth centuries], pp. 513-524, Wydawnictwo A. Marszałek, Toruń.

Marszałek, A. (1996), Z historii europejskiej integracji międzynarodowej [From the history of European international integration], Wydawnictwo Uniwersytetu Łódzkiego, Łódź.

Marszałek, A. (2000), Suwerenność a integracja europejska $w$ perspektywie historycznej. Spór o istote suwerenności i integracji [Sovereignty and European integration in the light of the historical perspective. Arguing about the essence of sovereignty and integration], Instytut Europejski, Łódź.
Marszałek, A. (2005), Suwerenność i integracja europejska w polskiej myśli naukowej i politycznej do końca XIX wieku [Sovereignty and the European integration in the Polish scientific and political thought until the end of the nineteenth century], Wydawnictwo Uniwersytetu Łódzkiego, Łodź.

Michałowski, S. (1999/2000), Wizje integrujacej się Europy w polskiej myśli politycznej okresu zaborów [Visions of building an integrated Europe in the light of Polish political thought in the period of the partitions], Annales Universitatis Mariae Curie-Skłodowskiej Vol. LIV/LV, Sectio F, pp. 75-86, Lublin.

Nowak, A. (2004), Europa narodów - wizja księcia Adama Jerzego Czartoryskiego [Europe of nations - the Prince Adam Jerzy Czartoryski's vision], in: Od imperium do imperium. Spojrzenie na historię Europy Środkowej [From empire to empire. An examination of the history of Central Europe], pp. 167-195, Wydawnictwo Arcana, Kraków.

Polska myśl polityczna XIX wieku. Wybór tekstów źródłowych $z$ komentarzem [Polish political thought of the nineteenth century. A selection of source texts with commentary] (1999), A selection made by: Juchnowski, J., Kalicki, W. and Tomaszewski, J., Wydawnictwo Uniwersytetu Wrocławskiego, Wrocław.

Polskie wizje Europy $w$ XIX $i$ XX wieku [Polish visions of Europe in the nineteenth and twentieth centuries] (2004), A selection made by Peter Oliver Loew, Wydawnictwo Uniwersytetu Wrocławskiego, Wrocław.

Skowronek, J. (1994), Adam Jerzy Czartoryski 1770-1861, Wiedza Powszechna, Warszawa.

Skrzetuski, J.K. (1772-1775), Projekt czyli ułożenie nieprzerwanego $w$ Europie pokoju [Project or arrangement for maintaining the undisturbed peace in Europe], in: Historia polityczna dla szlachetnej mtodzi [Political history for the noble youth], part I and II, printing by J.K.M. Rzeczypospolita, Scholarum Piarum, Warszawa. 
Staszic, S. (1954), Pisma filozoficzne $i$ społeczne [Philosophical and social works], vol. I, II, Państwowe Wydawnictwo Naukowe, Warszawa.

Staszic, S. (1959), Ród ludzki [The human race], vol. I, II, III, Państwowe Wydawnictwo Naukowe, Warszawa.

Tazbir J. (1961), Stanisław Lubieniecki, Przywódca ariańskiej emigracji [Stanisław Lubieniecki, the leader of Arian emigration], Państwowe Wydawnictwo Naukowe, Warszawa.

Tazbir J. (2003), Stando Lubentius moriar. Biografia Stanisława Lubienieckiego [Stando Lubentius moriar. A biography of Stanisław Lubieniecki], Wydawnictwo Iskry, Warszawa.
Wierzbicki A. (2009), Europa $w$ polskiej myśli historycznej i politycznej XIX $i$ XX wieku [Europe in Polish historical and political thought of the nineteenth and twentieth centuries], Centrum Europejskie Natolin, Warszawa.

Życki J. (1932), Polskie tradycje pokojowe [Polish peace traditions], in: Memoriat króla Stanisława Leszczyńskiego o zabezpieczeniu pokoju powszechnego [The king Stanisław Leszczyński's memorandum concerning the guarantees for universal peace], Wydawnictwo Artystyczne, Warszawa. 